\title{
GROWTH PERFORMANCE OF OSSIMI LAMBS AS AFFECTED BY TREATED RICE STRAW BY ENZYMES ZAD OR EFFECTIVE MICROORGANISMS
}

\author{
A. A. A. I. Gomaa M. Y. Mohamed, Fatma E. Saba, E.M.M. Ibrahim, A. A. El Badawy and A. A. \\ El-Giziry
}

Animal Production Research Institute, Agricultural Research Center, Ministry of Agriculture, Egypt.

Correspondence author: abdelhameed_20@yahoo.com

(Received 1/3/2016, accepted 24/5/2016)

\section{SUMMARY}

$\mathrm{T}$ he present study aimed to investigate the effect of bacterial enzymes (ZAD) or effective microorganisms (EM) treated with rice straw on, digestibility, growth performance and economic efficiency of Ossimi sheep. Twenty four lambs (12 males and 12 females) were randomly divided into three groups where first group fed on ration consisted of $(60 \%$ concentrate feed mixture (CFM) and $40 \%$ rice straw (RS) and served as control ration, and second group (R2) fed on (60\% CFM and 40\% RS+ZAD) and the third group (R3) fed on ration3 (60\% CFM and 40\% RS+EM).Results showed that both the ration included treated rice straw $\left(\mathrm{R}_{2}\right.$ and $\left.\mathrm{R}_{3}\right)$ increased of $\mathrm{CP}, \mathrm{EE}$ and Ash contents compared to non-treated rice straw ration $\left(\mathrm{R}_{1}\right)$. While $\mathrm{CF}$ content had the opposite trend. Control ration (R1) recorded the lowest of DM, OM, CP, EE, CF and NFE digestibilties compared to tested one which giving RS treated with ZAD or EM (R2 and R3). Also R2 and R3 had the highest values of TDN, DCP and DE compared to those of R1. Feed conversion of ratio was improved significantly $(\mathrm{P}<0.05)$ with ZAD or EM included rations (R2 and R3) compared with (R1). Blood parameters were positively affected by ZAD and EM ration. Growth performance (final weight, total gain and daily gain) were significant higher for both tested rations (R2\&R3) than those of control one (R1). Also, economical efficiency of tested ration was markedly improved due to the inclusion treated rice straw in these rations.

Keywords: ZAD, EM, biological treatment straw and sheep.

\section{INTRODUCTION}

Ruminants in many tropical and development countries subsist mainly on crop residue based diets. The increasing expansion of agro-industrial activity over the last few years has led to an annual production of a large quantity of lingo-cellulosic residues all over the world. The major agricultural byproducts which classified as poor quality roughage are for instance rice straw, rice husk, wheat straw, sugarcane tops and bagasse (Saritha, 2012). Althougha vast energy potential is locked in these lingocellulosic crop residues, these are not utilized to their fullest potential for ruminants feeding due to poor digestibility, low nitrogen and mineral contents which rendered them to be classified under nonmaintenance type of feeds. Also, the covalent encrustation of plant cell wall with lignin prevents their biodegradation in the rumen. Therefore various physical, chemical and biological treatments have been tried, which are known to improve feed quality either by increasing digestibility or by enhancing palatability.

Gomaa et al.(2012) concluded that treating rice straw with bacterial enzymes (ZAD compound) improved significantly digestibility coefficients, chemical composition and fiber fraction of ration fed to the Ossimi rams. Also, treating rations with ZAD compound increased TDN and digestibility of crude protein without any abnormal signs on blood or rumen parameters. In addition to a number of studies showed that enzymes improved cattle performance, but no improvement was observed in others. Apparently, the inconsistent results from those studies can be contributed to a number of factors, including diet composition, type of enzyme preparation, complement of enzyme additives, and amount of enzyme provided, enzyme stability and method of application (Yang et al., 1999). 


\section{Gomaa et al.}

Effective micro-organism (EM) is a product characterized by a mix of three major groups: i.e. photosynthetic bacteria, lactobacillus bacteria and yeasts and/or fungi (Higa and Wididana, 2007). The EM compound could better used as a biological inoculant to improve the nutritive value nonconventional feedstuffs (poor quality roughage) like rice straw, coffee pulp, husk, and others (Yonatan et al., 2014). Microorganisms in EM assist one another for survival in a food chain system and thereby form a synergy that fights off pathogens and microorganisms. EM is self-sterilizing ( $\mathrm{pH}$ between 3.4-3.7); therefore, pathogens cannot survive in EM (EMROSA, 2006).In addition, supplementation of EM with regular diet can enhance feed consumption and absorption of nutrients(Whitely et al., 2009). Also, a positive impact of EM supplementation on feed intake, weight gain and feed conversion in ruminants has been reported by Whitely et al., 2009. Moreover, improved animals performance was detected by yeast culture supplementation to ruminant diets and also found to increase glucose concentration (Sharma et al., 1998), blood total protein(El-Shaer, 2003)and decrease cholesterol (Fayed et al., 2005). The purpose of this study is to investigate the potentiality of rice straw that treated by ZAD and EM on productive performance of Ossimi lambs. This goal will be accomplished through digestion trail using Ossimi rams, and feeding trial on growing lambs for measuring blood parameters, feed intake, feed conversion, growth rate, body dimensions and economic efficiency of the experimental rations.

\section{MATERIALS AND METHODS}

This study was carried out to investigate the effect of biological treatments (bacterial enzyme; ZAD or effective microorganisms; EM) on poor quality roughage (rice straw RS) to improve growth performance of sheep.

The present study was carried out at Sids Experimental Station belonging to, Animal Production Research Institute (APRI), Agriculture Research Center, Ministry of Agriculture, located at BeniSuef governorate in middle Egypt.

\section{Ensiling procedures:}

Straw bales ensiled in two heaps where the first one was mixed with bacterial enzymes (ZAD), that already as a compound of enzymes separated from anaerobic bacteria of the rumen. It contains a mixture of cellulase, hemicellulase, protease and alpha amylase enzymes (Gomaa et al., 2012). The heap second of straw was mixed with effective microorganisms (EM), which represent with is a product that consisted of a mix of aerobic and anaerobic microorganisms with three major groups: i.e. photosynthetic bacteria, lactobacillus bacteria and yeasts and/or fungi (Higa and Wididana, 2007). The microbial inoculation was prepared as follows: mixing package of 1 liter to 100 liter of water and left for $2 \mathrm{~h}$ and sprayed on 50 tons of rice straw and squeezed well. Heaps were covered by double-layer of linoleum plastic and straw bales closely tighten coverage. Samples from the two heaps were taken after 60 days for analysis to examine of roughage quality.

\section{Animals and feeding:}

A 196-d comparative feeding trial was carried out using twenty four Ossimi lambs (12 male \& 12 female) to study the effect of biological treatments of rice straw (RS) by ZAD or EM on their growth performance in comparison with the untreated one. Lambs of an average $16.6 \mathrm{~kg}$ body weight were divided into three similar groups using $60 \%$ of their rations from concentrate feed mixture (CFM) while the roughage portion was covered by $40 \%$ as untreated-RS, ZAD-RS or EM-RS for R1 (control, R2 and $\mathrm{R} 3$ as tested ration, respectively, as are presented in Table (1). Daily ration were fed to cover the nutritional requirements for growing lambs according to NRC (1985). Animals were housed in a semi open shaded yard and mineral-vitamin blocks were freely available for liking along the experimental period. Weighs of lambs were recorded biweekly intervals for consecutive days before morning feeding and drinking. Daily gain, feed intake, and feed conversion ration were determination and also body dimensions were recorded monthly.

The chemical compositions of ingredients as well as the tested rations are present in Table (2). Nutrient digestibility and feeding values for experimental rations were determined by nine rams using in indirect method as mentioned by (Abou-Raya, 1967) for 22 days as 15 days preliminary period followed by 7 days as collected period.Animals were divided to three groups ( 3 in each) fed the experimental rations as presented in Table (1). Ninety percent of ad-libtum intake, in preliminary period, was offered for each ram (in 2 meals at 9.00 a.m. and 4.00 p.m.) during the days of collection period. Water was available at all times. Daily fresh feces from each ram was weighed during the collection period and 
representative samples of each collection was taken and dried in forced air oven at $65^{\circ} \mathrm{C}$ for $48 \mathrm{~h}$. Dried samples of each ram at the end of collection period were thoroughly mixed, ground and kept for chemical analysis.Chemical analysis of the sampled rations and feces were carried out to determine DM, CP, CF, EE and ash according to the method of AOAC (1995). While NFE values were calculated by differences. Total digestible nutrients (TDN) and digestible crude protein (DCP) calculated according to classic formula of McDonald et al. (1995). While digestible energy (DE Mcal/kg DM) was calculated according to NRC (1985).

Table (1): Formulation of the experimental rations.

\begin{tabular}{lccc}
\hline \multirow{2}{*}{ Ingredients } & \multicolumn{3}{c}{$\%$ on DM basis } \\
\cline { 2 - 4 } & $\mathrm{R}_{1}$ (control) & $\mathrm{R}_{2}$ & $\mathrm{R}_{3}$ \\
\hline CFM & 60 & 60 & 60 \\
RS & 40 & -- & -- \\
RS ZAD & -- & 40 & -- \\
RS EM & -- & -- & 40 \\
\hline
\end{tabular}

CFM: Concentrate feed mixture contained $24 \%$ cotton seed meal; $40 \%$ wheat bran; $30 \%$ yellow Corn $1.5 \%$ lime stone; $1 \%$ sodium chloride, $0.5 \%$ vitamins and mineral mixture and $3 \%$ molasses.

RS: rice straw. $\quad R S Z A D$ : rice straw treated with ZAD. $\quad R S$ EM: rice straw treated with EM.

\section{Blood samples and serum analysis:}

Blood samples of lambs were collected from the jugular vein in the morning before drinking and feeding at the beginning of the experiment and monthly along the experimental period. The collected blood samples were centrifuged at $3000 \mathrm{r}$. p. m. for 15 minutes and the obtained clear samples serum were stored at $-20^{\circ} \mathrm{C}$ until analysis. Concentrations of total protein and albumin were estimated in serum using kits of Diamond Diagnostic, EC Hannover, Germany. Globulin level was calculated by the difference between total protein and albumin. Glucose and cholesterol were quantified in serum by using kits of Spinreact, S.A.U. Ctra. Santa Coloma, 7 E-17176 SantEsteve de Bas (GI) Spain by means of spectrophotometer. Aspartate aminotransferase (AST) and alanine aminotransferase (ALT) were determined as described by Reitman and Frankel (1957).

\section{Economic efficiency:}

Economic efficiency was calculated on the basis of daily feed cost and price of daily body weight gain. Prices of feedstuffs and feed additives on were 2.52 and $0.45,40.00$ and $3.00 \mathrm{LE} / \mathrm{kg}$ for concentrate feed mixture, rice straw, ZAD and EM, respectively. While, price of live body weight $=40.0$ $\mathrm{LE} / \mathrm{kg}$.

\section{Statistical analyses:}

Data were statistically analyzed using the general linear model procedure (SAS, 2002). The differences among means were tested using Duncan's Multiple-rang test (Duncan, 1955). The model used in statistical analysis was:

$$
Y_{i j}=\mu+R_{i}+e_{i j}
$$

Where:

$\mathrm{Y}_{\mathrm{ij}}=$ an observation

$\mu=$ overall means

$\mathrm{R}_{\mathrm{i}}=$ effect of treatment $(\mathrm{i}=$ control, $\mathrm{ZAD}, \mathrm{EM})$

$\mathrm{e}_{\mathrm{ij}}=$ random error 


\section{RESULTS AND DISCUSSION}

\section{Chemical composition:}

Chemical composition of ingredients and the experimental rations are present in Table (2). Results showed that both treated rice straw and their rations were markedly increased CP, EE and Ash contents compared to un-treated rice straw and their ration. While CF content had opposite trend among these dietary treatments. These results to large extent due to adding ZAD and EM which improve value straws, stover and other nutritive quality and value of high fiber feedstuffs. These results in agreement with findings of Gomaa et al. (2012) who reported that significant decrease was observed in CF for rations treated with ZAD compared to non-treated one, while CP content had opposite trend. Also, ELmoghazy et al. (2015) indicated that the treatment in which five microorganisms were used showed that CF was significantly decreased from 33.15 to 27.14 while CP was significantly increased from 5.61 to 11.40 . In addition, Abdel-Khalek et al. (2012) revealed that both biological treatment (1 or 1.5\% EM) slightly increased contents of OM and NFE, while decreased EE and ash contents in diet of rabbits. However, considerable increase in $\mathrm{CP}$ and reduction $\mathrm{CF}$ contents was observed, in particular in diet treated with $1.5 \%$ EM.

\section{Nutrients digestibility and nutritive values of the experimental rations:}

Digestion coefficients of the experimental rations fed to Ossimi rams are shown in Table (3). Data indicated that $\mathrm{R}_{1}$ (control) recorded the lowest of DM, OM, CP, EE, CF and NFE digestibilities compared to treated rations with $Z A D$ and $\operatorname{EM}\left(R_{2}\right.$ and $\left.R_{3}\right)$. In other words, almost both biological treatments (ZAD\& EM) has caused significant improvement in most nutrient digestibility values in comparison with untreated one (control). On the same time, there were no significant difference between R2 and R3 respecting all nutrient digestibility values.

The lower digestibility coefficients of CF in the rations $\left(\mathrm{R}_{1}, \mathrm{R}_{2}\right.$ and $\left.\mathrm{R}_{3}\right)$ may be due to the higher NFE which may inhibit the activity of cellulolytic and hemi-cellulolytic microorganisms, leading to a decrease in the availability and utilization of CF in the rumen and could have adverse effects on the digestibility coefficients of such nutrient. These results are in agreement with those obtained by Gomaa et al. (2012) who observed that treated rice straw- ration with ZAD had the best estimates of digestibility and fiber fractions compared to non-treated rations. Also, Yonatan et al. (2014) reported that there was significant $(\mathrm{P}<0.001)$ improvement in in-vitro dry matter digestibility of coffee husk ensiled with the EM in comparison with untreated one.

Table (2): Chemical composition of ingredients and experimental rations (on DM basis).

\begin{tabular}{|c|c|c|c|c|c|c|c|}
\hline Item & $\mathrm{DM}$ & $\mathrm{OM}$ & $\mathrm{CP}$ & $\mathrm{EE}$ & $\mathrm{CF}$ & NFE & Ash \\
\hline CFM & 90.64 & 91.72 & 16.20 & 4.53 & 15.82 & 55.17 & 8.28 \\
\hline $\mathrm{RS}$ & 91.13 & 85.55 & 3.41 & 1.20 & 38.33 & 42.61 & 14.45 \\
\hline RS ZAD & 90.51 & 82.01 & 6.08 & 1.78 & 31.08 & 43.07 & 17.99 \\
\hline RS EM & 88.15 & 83.65 & 7.78 & 1.57 & 33.35 & 40.95 & 16.35 \\
\hline \multicolumn{8}{|l|}{$\underline{\text { Rations: }}$} \\
\hline $\mathrm{R}_{1}$ & 90.84 & 89.25 & 11.08 & 3.20 & 24.82 & 50.15 & 10.75 \\
\hline $\mathrm{R}_{2}$ & 90.59 & 87.84 & 12.15 & 3.43 & 21.93 & 50.33 & 12.16 \\
\hline $\mathrm{R}_{3}$ & 89.64 & 88.49 & 12.83 & 3.35 & 22.83 & 49.48 & 11.51 \\
\hline
\end{tabular}

The feeding values of the experimental rations in terms of TDN, DCP and DE on DM basis are present in Table (3). It could be noticed that rations included RS treated by ZAD or EM $\left(\mathrm{R}_{2}\right.$ and $\left.\mathrm{R}_{3}\right)$ had the highest values of TDN, DCP and DE compared to untreated ration $\left(R_{1}\right)$. There were significant $(\mathrm{P}<0.05)$ differences in TDN, DCP and DE among these rations. Similar results were obtained by several 
authors (Gomaa et al., 2012 and Woju, 2010) who indicated that bacterial enzymes (ZAD) and effective microorganism (EM) had a positive effect on nutritive value and nitrogen balance of sheep. Also, AbdelKhaleket al., (2012) found that EM -treated diet markedly improved feeding values as TDN and DCP as compared to the untreated one (control) by rabbits.

Table (3): Digestibility coefficients and feeding values of the experimental rations fed to Ossimi rams.

\begin{tabular}{|c|c|c|c|c|}
\hline \multirow{2}{*}{ Item } & \multicolumn{3}{|c|}{ Ration } & \multirow{2}{*}{ Sig. } \\
\hline & $\mathrm{R}_{1}$ (control) & $\mathrm{R}_{2}$ & $\mathrm{R}_{3}$ & \\
\hline \multicolumn{5}{|c|}{ Digestibility coefficients, \%: } \\
\hline DM & $79.39 \pm 1.08^{\mathrm{b}}$ & $85.74 \pm 0.87^{\mathrm{a}}$ & $84.43 \pm 0.70^{\mathrm{a}}$ & $* *$ \\
\hline $\mathrm{OM}$ & $67.06 \pm 2.10^{\mathrm{b}}$ & $74.42 \pm 1.49^{\mathrm{a}}$ & $74.42 \pm 1.13^{\mathrm{a}}$ & $*$ \\
\hline $\mathrm{CP}$ & $56.78 \pm 4.72^{b}$ & $79.29 \pm 6.69^{\mathrm{a}}$ & $68.80 \pm 1.12^{\mathrm{ab}}$ & $*$ \\
\hline $\mathrm{EE}$ & $67.11 \pm 0.39^{b}$ & $82.68 \pm 2.21^{\mathrm{a}}$ & $79.63 \pm 2.22^{\mathrm{a}}$ & $* *$ \\
\hline $\mathrm{CF}$ & $51.49 \pm 1.36^{\mathrm{b}}$ & $57.22 \pm 0.67^{\mathrm{a}}$ & $55.65 \pm 1.63^{\mathrm{ab}}$ & $*$ \\
\hline NFE & $78.10 \pm 2.54^{\mathrm{b}}$ & $81.93 \pm 0.78^{\mathrm{a}}$ & $84.74 \pm 1.29^{\mathrm{ab}}$ & $*$ \\
\hline \multicolumn{5}{|c|}{ Feeding values on DM basis, \%: } \\
\hline TDN & $63.06 \pm 1.83^{\mathrm{b}}$ & $70.01 \pm 1.18^{\mathrm{a}}$ & $69.36 \pm 0.90^{\mathrm{a}}$ & $*$ \\
\hline DCP & $6.29 \pm 0.52^{b}$ & $10.17 \pm 0.86^{\mathrm{a}}$ & $8.36 \pm 0.14^{\mathrm{a}}$ & $* *$ \\
\hline DE (M cal/kg DM) & $2.67 \pm 0.08^{\mathrm{b}}$ & $3.00 \pm 0.06^{\mathrm{a}}$ & $2.95 \pm 0.04^{\mathrm{a}}$ & $*$ \\
\hline
\end{tabular}

$a$ and $b$ : Means in the same row followed by the same letter are not significantly different $(P>0.05)$.

*: Significant at $(P<0.05)$.

**: Significant at $(P<0.01)$.

\section{Feed intake and feed conversion}

Data of Table (4) indicated that daily feed intake and feed unit intake as TDN and DCP of both sexlambs were higher significantly $(\mathrm{P}<0.05)$ when ZAD or EM included at $0.3 \%$ in the rations $\left(\mathrm{R}_{2}\right.$ and $\left.\mathrm{R}_{3}\right)$ compared with the control $\left(\mathrm{R}_{1}\right)$. Also, feed conversion of ratio was improved significantly $(\mathrm{P}<0.05)$ when $\mathrm{RS}$ treated by ZAD or EM included the tested rations (R2 and R3) compared with control one (R1). These results are in agreement with the findings of , Abdel-Khalek et al. (2003), Gomaa et al. (2012) and Woju (2010) who reported that ZAD or EM which added to diets of sheep and dairy cows had responsible to improve the feed intake and feed conversion for these diets and animals

\section{Blood parameters:}

Blood parameters (Table 5) showed significant $(\mathrm{P}<0.05)$ increase in growing male lamb's total protein (TP) with ZAD ration $\left(R_{2}\right)$ and insignificant increase with EM ration $\left(R_{3}\right)$ compared to that of control $\left(R_{1}\right.$. In both ZAD and EM treatment groups $\left(R_{2}\right.$ and $\left.R_{3}\right)$ recorded significant higher values of albumin (Alb) concentration than that of control group $\left(\mathrm{R}_{1}\right)$, while, globulin (Glob) concentration didn't show significant differences among the experimental groups. Regarding female lambs, the concentration of TP, ALP and GLOB did not significantly affected by dietary treatments. It is worth noting that the increase in TP concentration in both tested groups was associated with significant $(\mathrm{P}<0.05)$ improvement in $\mathrm{CP}$ digestibility and nutritive values as DCP in both tested groups compared to that of control one (Table 4).These results are on line of the findings of Abdel-Khalek et al. (2012) who indicated that serum TP, Alb and Glob were significantly $(\mathrm{P}<0.05)$ higher in both EM treatment than in the control one with rabbits. Also, Gomaa et al. (2012) reported that treating RS by ZAD before incision sheep ration had a significantly $(\mathrm{P}<0.05)$ higher level of blood TP than that of those fed untreated RS-ration $(\mathrm{R} 1)$ 
Table (4): Daily feed intake and feed conversion of ram and ewe lambs fed the experimental rations.

\begin{tabular}{|c|c|c|c|c|c|c|}
\hline \multirow{2}{*}{ Item } & \multicolumn{3}{|c|}{ Male lambs } & \multicolumn{3}{|c|}{ Female lambs } \\
\hline & $\overline{\mathrm{R}_{1}}$ & $\mathrm{R}_{2}$ & $\mathrm{R}_{3}$ & $\mathrm{R}_{1}$ & $\mathrm{R}_{2}$ & $\mathrm{R}_{3}$ \\
\hline \multicolumn{7}{|l|}{$\begin{array}{l}\text { Daily DM intake, } \\
\text { Kg/head: }\end{array}$} \\
\hline CFM & $0.72 \pm 0.01^{\mathrm{c}}$ & $0.84 \pm 0.01^{\mathrm{a}}$ & $0.77 \pm 0.01^{\mathrm{b}}$ & $0.67 \pm 0.01^{\mathrm{b}}$ & $0.74 \pm 0.01^{\mathrm{a}}$ & $0.71 \pm 0.01^{\mathrm{a}}$ \\
\hline RS & $0.48 \pm 0.01^{\mathrm{c}}$ & $0.56 \pm 0.01^{\mathrm{a}}$ & $0.51 \pm 0.01^{\mathrm{b}}$ & $0.44 \pm 0.01^{\mathrm{b}}$ & $0.49 \pm 0.01^{\mathrm{a}}$ & $0.48 \pm 0.01^{\mathrm{a}}$ \\
\hline Total DMI, & $1.20 \pm 0.01^{\mathrm{c}}$ & $1.40 \pm 0.01^{\mathrm{a}}$ & $1.28 \pm 0.01^{\mathrm{b}}$ & $1.11 \pm 0.01^{\mathrm{b}}$ & $1.23 \pm 0.02^{\mathrm{a}}$ & $1.19 \pm 0.01^{\mathrm{a}}$ \\
\hline \multicolumn{7}{|c|}{$\begin{array}{l}\text { Daily feed unit intake } \\
\text { K/ head: }\end{array}$} \\
\hline TDN & $0.76 \pm 0.01^{\mathrm{c}}$ & $0.98 \pm 0.01^{\mathrm{a}}$ & $0.89 \pm 0.01^{\mathrm{b}}$ & $0.70 \pm 0.01^{b}$ & $0.86 \pm 0.01^{\mathrm{a}}$ & $0.82 \pm 0.01^{\mathrm{a}}$ \\
\hline $\mathrm{DCP}$ & $0.07 \pm 0.01^{\mathrm{c}}$ & $0.14 \pm 0.01^{\mathrm{a}}$ & $0.11 \pm 0.01^{\mathrm{b}}$ & $0.07 \pm 0.01^{\mathrm{c}}$ & $0.13 \pm 0.01^{\mathrm{a}}$ & $0.10 \pm 0.01^{\mathrm{b}}$ \\
\hline Feed conversion: & & & & & & \\
\hline (DM/ gain, kg/ kg) & $10.26 \pm 0.28^{\mathrm{a}}$ & $8.97 \pm 0.13^{b}$ & $9.41 \pm 0.13^{\mathrm{b}}$ & $11.10 \pm 0.33^{\mathrm{a}}$ & $10.08 \pm 0.09^{b}$ & $10.26 \pm 0.10^{\mathrm{b}}$ \\
\hline
\end{tabular}

$a, b$ and $c:$ Means within each row with different superscripts are significantly differ $(P<0.05)$.

Results in Table (5) showed that concentrations of glucose were significantly $(\mathrm{P}<0.05)$ higher in both ZAD and EM inoculated groups $\left(R_{2}\right.$ and $\left.R_{3}\right)$ than in the control group $\left(R_{1}\right)$ for male lambs, while, the differences were not significant among the experimental groups for female lambs. The higher glucose level in blood may be related to rapid rate of hydrolysis and absorption of the dietary carbohydrates in the alimentary tract. Similar results were obtained by (Hussein, 2014) who reported that higher significantly $(\mathrm{P}<0.05)$ blood glucose concentration in lambs fed diets supplemented with probiotics, and this increase might be due to a temperate improvement gluconeogenesis and increased lactose absorption ( de Valdezet al., 1997). Also, Abdel-Khalek et al. (2012) revealed that serum glucose significantly $(\mathrm{P}<0.05)$ higher in both EM treatment than in the control one of rabbit.

The results in (Table 5) demonstrated that cholesterol concentrations were significantly $(\mathrm{P}<0.05)$ higher in with only EM inoculated group $\left(R_{3}\right)$ than in the control group $\left(R_{1}\right)$ for male lambs, while $R 2$ significant higher than the value of control (R1). However, ELmoghazy et al. (2015) showed that microbiological treatments of rice straw had no effect on values of the plasma total lipids of sheep. In contrast, Esatu et al. (2011) found that cholesterol level of blood taken from broilers fed with control diet (no EM supplemented) showed significantly $(\mathrm{P}<0.05)$ higher than that of groups fed with EM in different forms.

Regarding the enzymatic activities of liver functions, blood concentrations of AST and ALT were not affected significantly by ZAD and EM treatments, either in male or female lambs (Table 5). This result proved that enzymatic and microbiologal treatments of rice straw by (ZAD or EM) had no effect on liver function. The same result was obtained by ELmoghazy et al. (2015) who investigated that the effect of microbiological treatments of rice straw on liver function of sheep. Also, these results agreed with those reported by Gomaa et al. (2012) who indicated that treating rations with ZAD reflected low level of ALT and AST with no significant differences among experimental treatments.

\section{Body dimensions:}

The values for height at withers (HWs), rump height (RH), body length (BL), sternum height (SH), body depth (BD), bicostal diameter (BD), rump width (RW), rump length (RL), head length (HL), heart girth (HG), for male and female lambs fed the experimental rations are shown in Table (6). The results revealed that male lambs fed treated rice straw with ZAD $\left(\mathrm{R}_{2}\right)$ had significantly higher values of $\mathrm{HW}, \mathrm{RH}$ and $\mathrm{SH}$ as compared to treated rice straw with $\mathrm{EM}\left(\mathrm{R}_{3}\right)$ and ram lambs fed un-untreated rice straw $\left(\mathrm{R}_{1}\right)$. Adding ZAD and EM to male lambs rations $\left(\mathrm{R}_{2}\right)$ increased $\mathrm{RH}$ significantly $(\mathrm{P}<0.05)$ compared to the EM (R3) and control $\left(\mathrm{R}_{1}\right)$. In female lambs, the most body dimensions were not significant among the tested rations, while $\mathrm{BD}$ values were increased significantly $(\mathrm{P}<0.05)$ in 
$\mathrm{R}_{2}$ compared to $\left(\mathrm{R}_{1}\right.$ and $\left.\mathrm{R}_{3}\right)$. The superiority of ZAD or EM rations $\left(\mathrm{R}_{2}\right.$ and $\left.\mathrm{R}_{3}\right)$ compared to the control $\left(\mathrm{R}_{1}\right)$ in some of body measurements might be due to a positive relation with the growth performance of the tested lambs (Table, 6).

Table (5): Blood parameters of male and female lambs fed the experimental rations.

\begin{tabular}{|c|c|c|c|c|}
\hline \multirow{2}{*}{ Item } & \multicolumn{3}{|c|}{ Experimental rations } & \multirow{2}{*}{ Sig } \\
\hline & $\mathrm{R}_{1}$ & $\mathrm{R}_{2}$ & $\mathrm{R}_{3}$ & \\
\hline \multicolumn{5}{|l|}{ Male lambs: } \\
\hline Total protein $(\mathrm{g} / \mathrm{dl})$ & $7.93 \pm 0.33^{b}$ & $8.74 \pm 0.25^{\mathrm{a}}$ & $8.48 \pm 0.25^{\mathrm{ab}}$ & $*$ \\
\hline Albumin (g/dl) & $3.84 \pm 0.18^{\mathrm{b}}$ & $4.49 \pm 0.14^{\mathrm{a}}$ & $4.56 \pm 0.14^{\mathrm{a}}$ & $* *$ \\
\hline Globulin (g/dl) & $4.10 \pm 0.3^{\mathrm{a}}$ & $4.25 \pm 0.20^{\mathrm{a}}$ & $3.92 \pm 0.21^{\mathrm{a}}$ & NS \\
\hline Glucose (mg/dl) & $94.44 \pm 4.27^{\mathrm{b}}$ & $109.09 \pm 5.08^{\mathrm{a}}$ & $115.66 \pm 3.31^{\mathrm{a}}$ & $* *$ \\
\hline Cholesterol (mg/dl) & $116.91 \pm 9.18^{b}$ & $132.10 \pm 12.37^{\mathrm{ab}}$ & $152.66 \pm 13.99^{\mathrm{a}}$ & $*$ \\
\hline ALT (U/L) & $14.99 \pm 0.89^{\mathrm{a}}$ & $13.78 \pm 0.62^{\mathrm{a}}$ & $13.34 \pm 0.49^{\mathrm{a}}$ & NS \\
\hline AST (U/L) & $33.72 \pm 2.47^{\mathrm{a}}$ & $33.51 \pm 2.78^{\mathrm{a}}$ & $34.33 \pm 1.55^{\mathrm{a}}$ & NS \\
\hline \multicolumn{5}{|l|}{ Female lambs: } \\
\hline Total protein $(\mathrm{g} / \mathrm{dl})$ & $8.03 \pm 0.28^{\mathrm{a}}$ & $8.39 \pm 0.23^{\mathrm{a}}$ & $8.17 \pm 0.30^{\mathrm{a}}$ & NS \\
\hline Albumin (g/dl) & $4.42 \pm 0.22^{\mathrm{a}}$ & $4.35 \pm 0.12^{\mathrm{a}}$ & $4.21 \pm 0.21^{\mathrm{a}}$ & NS \\
\hline Globulin (g/dl) & $3.61 \pm 0.16^{\mathrm{a}}$ & $4.04 \pm 0.16^{\mathrm{a}}$ & $3.96 \pm 0.21^{\mathrm{a}}$ & NS \\
\hline Glucose (mg/dl) & $103.54 \pm 6.64^{\mathrm{a}}$ & $103.03 \pm 6.11^{\mathrm{a}}$ & $99.50 \pm 4.82^{\mathrm{a}}$ & NS \\
\hline Cholesterol (mg/dl) & $95.65 \pm 6.80^{\mathrm{b}}$ & $141.06 \pm 10.73^{\mathrm{a}}$ & $126.57 \pm 7.68^{\mathrm{a}}$ & $*$ \\
\hline ALT (U/L) & $14.35 \pm 0.43^{\mathrm{a}}$ & $13.71 \pm 0.21^{\mathrm{a}}$ & $15.04 \pm 0.64^{\mathrm{a}}$ & NS \\
\hline AST (U/L) & $36.56 \pm 0.56^{\mathrm{a}}$ & $38.00 \pm 0.55^{\mathrm{a}}$ & $37.67 \pm 0.69^{\mathrm{a}}$ & NS \\
\hline
\end{tabular}

$\mathrm{a}$ and $\mathrm{b}$ : Means in the same row followed by the same letter are not significantly different $(\mathrm{P}>0.05)$.

*: Significant at $(P<0.05) . \quad$ **: Significant at $(P<0.01)$.

NS: Not significant.

Table (6): Live body dimensions (cm) of male and female lambs fed the experimental rations.

\begin{tabular}{lcccccc}
\hline \multirow{2}{*}{ Item } & \multicolumn{3}{c}{ Male lambs } & \multicolumn{3}{c}{ Female lambs } \\
\cline { 2 - 6 } & Control $\left(\mathrm{R}_{1)}\right.$ & $\mathrm{R}_{2}$ & $\mathrm{R}_{3}$ & Control $\left(\mathrm{R}_{1)}\right.$ & $\mathrm{R}_{2}$ & $\mathrm{R}_{3}$ \\
\hline Height at withers & $68.67 \pm 1.45^{\mathrm{b}}$ & $74.33 \pm 0.67^{\mathrm{a}}$ & $69.67 \pm 0.67^{\mathrm{b}}$ & $66.00 \pm 0.58$ & $67.33 \pm 0.33$ & $66.00 \pm 4.04$ \\
Rump height & $66.67 \pm 1.45^{\mathrm{b}}$ & $73.67 \pm 0.88^{\mathrm{a}}$ & $68.00 \pm 0.58^{\mathrm{b}}$ & $65.67 \pm 0.88$ & $69.67 \pm 0.88$ & $64.33 \pm 3.53$ \\
Body length & $66.00 \pm 2.31$ & $67.67 \pm 0.88$ & $68.00 \pm 3.21$ & $61.67 \pm 0.88$ & $63.00 \pm 1.73$ & $64.00 \pm 0.58$ \\
Sternum height & $49.67 \pm 2.03^{\mathrm{b}}$ & $56.00 \pm 2.00^{\mathrm{a}}$ & $50.67 \pm 0.88^{\mathrm{ab}}$ & $49.67 \pm 0.33$ & $48.67 \pm 0.33$ & $49.00 \pm 3.06$ \\
Body depth & $73.00 \pm 1.16$ & $77.33 \pm 1.33$ & $76.33 \pm 1.86$ & $69.00 \pm 0.58$ & $70.00 \pm 1.53$ & $71.67 \pm 3.84$ \\
Bicostal diameter & $13.67 \pm 0.33$ & $16.00 \pm 1.00$ & $15.00 \pm 0.58$ & $15.67 \pm 0.88^{\mathrm{b}}$ & $19.33 \pm 0.67^{\mathrm{a}}$ & $15.67 \pm 0.33^{\mathrm{b}}$ \\
Rump width & $18.00 \pm 0.58$ & $19.00 \pm 1.16$ & $19.33 \pm 1.45$ & $17.00 \pm 1.00$ & $17.00 \pm 0.01$ & $17.33 \pm 0.88$ \\
Rump length & $17.67 \pm 0.33^{\mathrm{b}}$ & $19.67 \pm 0.33^{\mathrm{a}}$ & $19.33 \pm 0.33^{\mathrm{a}}$ & $18.00 \pm 0.58$ & $18.67 \pm 0.33$ & $16.33 \pm 1.20$ \\
Heart girth & $76.00 \pm 0.01$ & $84.67 \pm 1.86$ & $81.67 \pm 2.19$ & $76.00 \pm 0.01$ & $77.67 \pm 2.40$ & $76.67 \pm 5.84$ \\
\hline
\end{tabular}

$a$ and $b$ : Means in the same row followed by the same letter are not significantly different $(P>0.05)$. 


\section{Gomaa et al.}

\section{Growth performance:}

Live body weight (initial and final), total gain and daily gain of male and female lambs fed $\mathrm{R}_{1}, \mathrm{R}_{2}$ and $R_{3}$ rations over 28 weeks growing period are presented in Table (7) and more illustrated Fig. (1). It is of interest to note that the values of final weight (FW), total gain (TG) and daily gain (DG) of two sex lambs fed $R_{2}$ and $R_{3}$ tended to be higher significant $(P<0.05)$ than those fed control $\left(R_{1)}\right.$. Growth performance (FW, TG and DG) was significant better with ZAD-RS ration (R2) than those EM-RS ration (R3) with male lambs, while non-significant difference between R2 and R3 and case of female lambs respecting growth performance. The superiority of lambs fed treated rice straw with ZAD $\left(\mathrm{R}_{2}\right)$ or EM $\left(\mathrm{R}_{3}\right)$ in their growth performance items compared red to lambs fed untreated rice straw $\left(R_{1}\right)$ may be attributed to the increasing of digestibility coefficients, nutritive values (Table 3), feed intake and feed conversion of ratio (Table 4), and consequently increased the total protein and glucose levels in blood of tested rations, lambs (Table 5). Inclusion of ensiled orange pulp in lamb diets with addition of exogenous enzymes improved the average live weight that probably due to the increased nutrients digestion of the diet, which attributable to improved feed efficiency and/or increased availability of nutrients to the animals (Gado et al., 2011). Beauchemin et al. (1995) indicated that the improved live weight with enzymes might be due to increased digestibility, which yields more energy and/or nutrient availability to rumen microbes. Probiotic compound are usually related to stimulation of cellulolytic and lactate utilization bacteria in the rumen, increased fiber digestion and increased flow of microbial protein from the rumen (Salem et al., 2004), which may be beneficial for good growth of lambs. Moreover, (Gado et al., 2009) indicated that enzymes have been shown to have marked positive effects on increasing the total microbial population in the rumen and in turn increased microbial protein synthesis in sheep.The result in this work agreed with those observed by Hussein, (2014) who reported that probiotics supplementation significantly $(\mathrm{P}<0.05)$ improved live body weight gain in both second $(5 \mathrm{~g} / \mathrm{kg})$ and third $(10 \mathrm{~g} / \mathrm{kg})$ groups compared to the control group in the experimental period. In addition, Safaa (2013) indicated that body weight and daily gain of broiler chickens were improved in response to dietary $6 \% \mathrm{ZADO}^{\circledR}$ compared to the other treatments that free from than supplement.

Table (7): Growth performance of male and female lambs fed the experimental rations.

\begin{tabular}{lcccc}
\hline \multirow{2}{*}{ Item } & \multicolumn{3}{c}{ Experimental rations } & Sig. \\
\cline { 2 - 4 } & $\mathrm{R}_{1}$ & $\mathrm{R}_{2}$ & $\mathrm{R}_{3}$ \\
\hline Male lambs: & $16.67 \pm 0.33$ & $16.67 \pm 0.33$ & $16.33 \pm 0.33$ & $\mathrm{NS}$ \\
Initial body weight $(\mathrm{kg})$ & $34.33 \pm 0.33^{\mathrm{c}}$ & $40.00 \pm 0.33^{\mathrm{a}}$ & $36.67 \pm 0.33^{\mathrm{b}}$ & $* *$ \\
Final body weight $(\mathrm{kg})$ & $17.67 \pm 0.67^{\mathrm{c}}$ & $23.33 \pm .33^{\mathrm{a}}$ & $20.33 \pm 0.33^{\mathrm{b}}$ & $* *$ \\
Total gain $(\mathrm{kg})$ & $117.78 \pm 4.45^{\mathrm{c}}$ & $155.55 \pm 2.22^{\mathrm{a}}$ & $135.55 \pm 2.22^{\mathrm{b}}$ & $* *$ \\
Average daily gain $(\mathrm{g})$ & & & & \\
Female lambs: & $16.67 \pm 0.33$ & $16.67 \pm 0.33$ & $16.67 \pm 0.33$ & $\mathrm{NS}$ \\
Initial body weight $(\mathrm{kg})$ & $31.67 \pm 0.33^{\mathrm{b}}$ & $35.00 \pm 0.58^{\mathrm{a}}$ & $34.00 \pm 0.58^{\mathrm{a}}$ & $* *$ \\
Final body weight $(\mathrm{kg})$ & $15.00 \pm 0.58^{\mathrm{b}}$ & $18.33 \pm 0.33^{\mathrm{a}}$ & $17.33 \pm 0.33^{\mathrm{a}}$ & $* *$ \\
Total gain $(\mathrm{kg})$ & $100.00 \pm 3.85^{\mathrm{b}}$ & $122.22 \pm 2.22^{\mathrm{a}}$ & $115.55 \pm 2.22^{\mathrm{a}}$ & $* *$ \\
Average daily gain $(\mathrm{g})$ & & & \\
\hline
\end{tabular}

$a$ and $b$ : Means in the same row followed by the same letter are not significantly different $(P>0.05)$.

**: Significant at $(P<0.01)$.

\section{Economic efficiency:}

Economic efficiency (Table 8) of feeding growing male and female lambs experimental so far depending on the cost of medium or good quality protein of their total ration. The present results revealed that marked improvement in feed cost per $\mathrm{Kg}$ gain to both rations having RS treated by ZAD or EM supplements, in comparison with control that free from treated RS. 


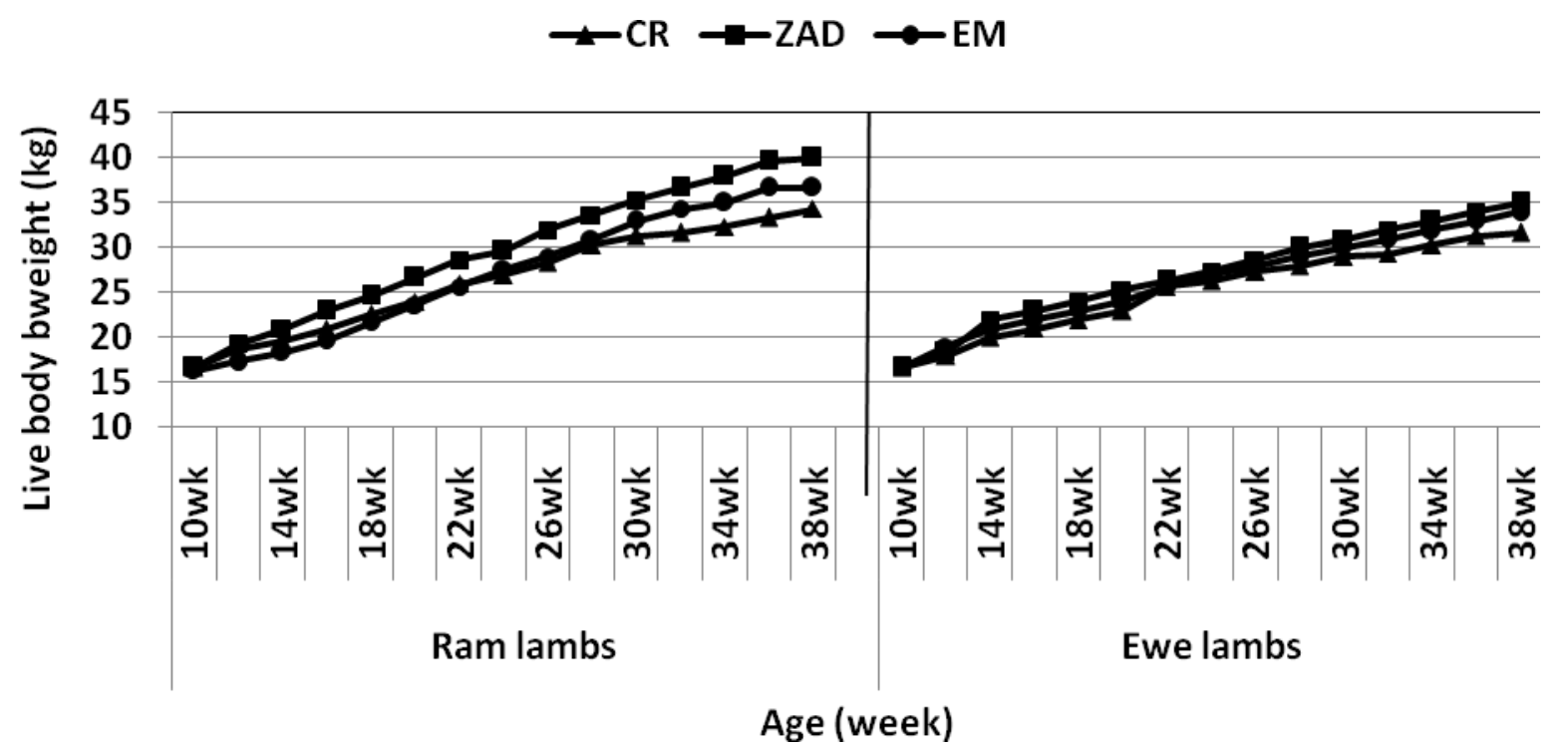

Fig. (1) Average live body weight of male and female lambs fed experimental rations.

Table (8): Economic efficiency of ram and ewe lambs fed the tested rations.

\begin{tabular}{|c|c|c|c|c|c|c|}
\hline \multirow{2}{*}{ Items } & \multicolumn{3}{|c|}{ Rams lamb } & \multicolumn{3}{|c|}{ Ewes lamb } \\
\hline & $\mathrm{R}_{1}$ & $\mathrm{R}_{2}$ & $\mathrm{R}_{3}$ & $\mathrm{R}_{1}$ & $\mathrm{R}_{2}$ & $\mathrm{R}_{3}$ \\
\hline \multicolumn{7}{|l|}{ Daily DM intake } \\
\hline TDMI, Kg/head/day & $1.20 \pm 0.01^{\mathrm{c}}$ & $1.40 \pm 0.01^{\mathrm{a}}$ & $1.28 \pm 0.01^{\mathrm{b}}$ & $1.11 \pm 0.01^{\mathrm{b}}$ & $1.23 \pm 0.02^{\mathrm{a}}$ & $1.19 \pm 0.01^{\mathrm{a}}$ \\
\hline $\begin{array}{l}\text { Daily body weight } \\
\text { gain, kg }\end{array}$ & $0.117 \pm 0.01^{\mathrm{c}}$ & $0.156 \pm 0.01^{\mathrm{a}}$ & $0.136 \pm 0.01^{\mathrm{b}}$ & $0.100 \pm 0.01^{\mathrm{b}}$ & $0.122 \pm 0.01^{\mathrm{a}}$ & $0.116 \pm 0.01^{\mathrm{ab}}$ \\
\hline \multicolumn{7}{|l|}{$\begin{array}{l}\text { Economic } \\
\text { efficiency: }\end{array}$} \\
\hline $\begin{array}{l}\text { Feed cost } \\
\text { (LE/head/day) }\end{array}$ & 2.03 & 2.37 & 2.17 & 1.89 & 2.09 & 2.01 \\
\hline $\begin{array}{l}\text { Cost of ZAD or EM } \\
\text { (LE/head/day) }\end{array}$ & -- & 0.067 & 0.005 & -- & 0.059 & 0.004 \\
\hline $\begin{array}{l}\text { Total cost } \\
\text { (LE/head/day) }\end{array}$ & 2.03 & 2.44 & 2.18 & 1.89 & 2.15 & 2.014 \\
\hline $\begin{array}{l}\text { Price of body } \\
\text { weight gain (LE) }\end{array}$ & 4.68 & 6.24 & 5.44 & 4.00 & 4.88 & 4.64 \\
\hline $\begin{array}{l}\text { *Economic } \\
\text { efficiency }\end{array}$ & 2.65 & 3.80 & 3.26 & 2.11 & 2.73 & 2.63 \\
\hline $\begin{array}{l}\text { Feed cost/ Kg gain } \\
\text { LE }\end{array}$ & 17.35 & 15.64 & 16.02 & 18.9 & 17.62 & 17.36 \\
\hline
\end{tabular}

$a, b$ and $c:$ Means within each row with different superscripts are significantly differ $(P<0.05)$.

Price of one $\mathrm{kg}$ (DM basis) of CM and rice straw 2.52 and $0.45 \mathrm{LE} /$ ton, respectively. Cost of ZAD and EM were 40 and $3.0 \mathrm{LE} / \mathrm{kg}$ and added by $0.3 \% / \mathrm{ton}$. While, price of live body weight $=40.0 \mathrm{LE} / \mathrm{kg}$.

Economic efficiency $=$ price of body weight gain - daily feed cost . 


\section{Gomaa et al.}

\section{CONCLUSION}

It could be concluded that the upgrading the nutritive value of rice by some biological methods (enzymes (ZAD) or effective microorganisms (EM)) (ensiling rice straw with ZAD or EM) and incorporated it in lambs, rations led to significant improvement in digestibility of rations, growth performance and nutritional economic efficiency of growing lambs. Meantime, inoculated rice straw by ZAD or EM need more research to know what is the optimum ratio of ZAD or EM can be used to get more of rice straw quality and profit for animal feeding.

\section{REFERENCES}

Abdel-Khalek, A.E. (2003). Productive and reproductive performance of primiparous and multiparous Friesian cows fed rations supplemented with yeast culture (Yea-Sacc1026). Egyptian J. Nutr. and Feeds, 6 (Special Issue): 1095-105.

Abdel-Khalek, A.E.; A.M. Abdelhamid; A.F. Mehrez and I. El-Sawy (2012): Growth performance, digestibility coefficients, blood parameters and carcass traits of rabbits fed biologically treated diets. J. Animal and Poultry Prod., Mansoura Univ., 3 (5): 227-239.

Abou-Raya, A. K (1967). Animal and poultry nutrition 1st Ed, (Text book in Arabic) Dar El-Marrf, Cairo, Egypt.

AOAC, (1995): Official Methods of Analysis, $16^{\text {th }}$ Ed. Association of Official Analytical Chemists, Washington, DC, USA.

Beauchemin, K.A.; L.M. Rode and V.J.H. Sewalt(1995). Fibrolytic enzymes increase fiber digestibility and growth rate of steers fed dry forages. Can. J. Anim. Sci. 75, 641-644.

de Valdez, G.F.; G. Martos; T.M. Taranto; G.L. Lorca; G. Oliver and A.P. de Ruiz Holgado (1997). Influence of beta-Galactosidase activity and cell viability of Lactobacillus reuteri when subjected to Freeze-Drying. Journal of Dairy Science 80: 1955-1958.

Duncan, D. B. (1955).Multiple ranges and multiple F. Test. Biometrics, 11: 1.

ELmoghazy, M. M.; M. H. El-Fadaly; T.H. Tag El-Din and H.A. Areda (2015). Effect of sheep diet containing microbiological treated rice straw on blood parameters and nitrogen balance. Journal Microbiology Research, 5 (2): 46-56.

El-Shaer, EKHI (2003). Nutritional studies in ruminants. "Effect of yeast culture supplementation and concentrate: roughage ratio on performance of growing lambs" $\mathrm{Ph}$. D. thesis submitted to Faculty of Agriculture, Mansoura university, Egypt.

EMROSA (2006). Effective microorganisms research organization in South Africa. Users manual.Emrosa, Inc. South Africa.

Esatu, W.; A. Melesse and T. Dessie (2011).Effect of Effective Microorganisms on growth parameters and serum cholesterol levels in broilers.African Journal of Agricultural Research Vol, 6 (16), pp, 3841-3846.

Fayed, A.M. ; M.A. El-Ashry; K.M. Youssef; F. A. Salem and H. A. Aziz (2005). Effect of feeding falvomycin or yeast as feed supplement on ruminal fermentation and some blood constituents of sheep in Sinai. Egyptian Journal of nutrition and feeds 8: 619-634.

Gado, H.M.; A.Z.M. Salem; N.E. Odongo and B.E. Borhami (2011): Influence of exogenous enzymes ensiled with orange pulp on digestion and growth performance in lambs. Anim. Feed Sci. Technol., 165: 131-136.

Gado, H.M.; A.Z.M. Salem; P.H. Robinson and M. Hassan (2009): Influence of exogenous enzymes on nutrient digestibility, extent of ruminal fermentation as well as milk production and composition in dairy cows. Anim. Feed Sci. Technol., 154: 36-46. 
Gomaa, R. ; H. Gado; H. El-Sayed; S. Abd El Mawla (2012). Usage of treated rice straw with exogenous anaerobic bacterial enzymes (ZAD) for Ossimi sheep.Annals of Agricultural Science (2012) 57(2), 183-190

Higa, T and G.N. Wididana (2007). The Concept and theory of Effective Microorganism: A New Dimension for Nature Farming. pp. 20-22. In J.F. Parr, S.B. Hornick, and M.E. Simpson (eds). Proceedings of the $2^{\text {nd }}$ International Conference on Kyusei Nature Farming.U.S.Department of Agriculture, Washington, D.C, USA.

Hussein, A. F. (2014). Effect of biological additives in growth indices and physiological responses of weaned Najdi ram lambs. Journal of Experimental Biology and Agricultural Sciences. 2 (6): 597-607.

McDonald, P. ; A.M. Edwards; G. F. D. Greenhalagh and C. A. Morgan (1995).Animal nutrition $5^{\text {th }}$ Ed., copyright licensing LTD., London.

NRC (1985).National research council.Nutrient requirements of sheep, national academy of science.Washington, D.C, USA.

Reitman, S. and S. Frankel (1957).A colorimetric method for the determination of serum glutamic oxalacetic and glutamic pyruvic trasaminases. Am. J. Clin. Pathol., 28: 56-63.

Safaa, H.M. (2013). Influence of dietary enzymes prepared at ensiling (ZADO ${ }^{\circledR}$ ) from hatch to 42 days of age on productivity, slaughter traits and blood constituents in broiler chickens. International Journal of poultry science 12 (9): 529-537.

Salem, A.Z.M.; M.M. El-Adawy; M.Z.M. Salem and A.A. Hassan (2004).Effect of probiotics feed as additives on the activity of isolated and characterized lactic acid intestinal bacteria to inhabit Escherichia coli-10 in sheep. Egyptian J. Nutr.Feeds. 7, 167-184.

Saritha, M. Arora, A. Lata (2012). Biological pretreatments of lingo-cellulosic substrates for enhanced delignification and enzymatic digestibility., Ind., J. microbial., 25, 122-130.

SAS (2002). User's Guide: Statistics, Version 9.0 Edition. SAS Institute Inc., Cary, NC, USA.

Sharma, R.; O.P. Nagia; M. Gupta and R. Sharma (1998).Effect of yeast culture (Saccharomysescerevisiae) plus growth medium supplementation on rimen fermentation in buffalo calves fed high roughage diet. International Journal of Animal Science 3:121-126.

Whitely, NC; D. Cazac; BJ. Rude; D. Jackson-O'Brien and S. Parveen (2009). Use of commercial Probiotics supplement in meat goat. Journal of Animal Science 87: 723-728.

Woju, C. W. (2010).Impact of effective microorganisms on feed intake, digestibility, growth and mixed internal parasitic load of local sheep at DebreZeit, Ethiopia. Addis Ababa Univerisity. http://agris.fao.org/agris-search/search.do?recordID=ET2009000016

Yang, W. Z.; K. A. Beauchemin and L. M. Rode (1999). Effects of an enzyme feed additive on extent of digestion and milk production of lactating dairy cows. J. dairy Sci 82: 391-403.

Yonatan, K.; S. Demeke; T. Tolemariam and Y. Getachew (2014).Effect of effective microorganism (EM) on the nutritive quality of coffee husk silage.International Journal of scientific \& Technology research. Vol. 3, Issue 7. 13-20. 


\section{Gomaa et al.}

الأداء الانتاجى للحملان الأوسيمى المذذاء على علائق تحتوي على قش الأرز المعامل انزيميا بالزاد أو المعامل ميكروبيا

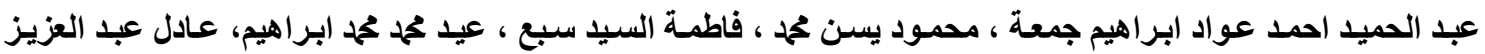
البديوى و عمرو على الجزيري

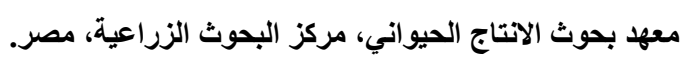

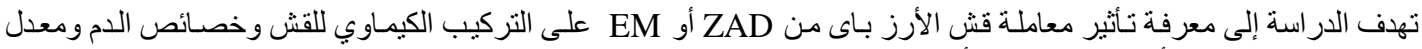

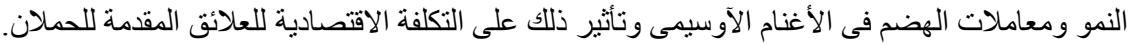

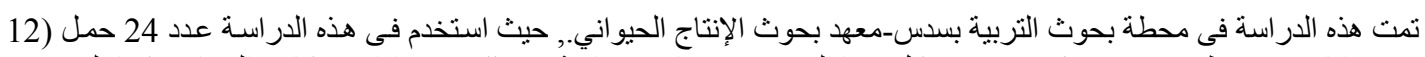
ذكور و 12 إناث) منوسط وزن 16.6 كجم وقسمت كل منها إلى 3 مجمو عات منساوية ( 4 ذكور +4 اناث) وكانت المجاميع كما يلي:

1. المجموعة الأولي: المقارنة (R1 ) قش أرز غير معامل + مخلوط العلف المركز (40: 60\%).

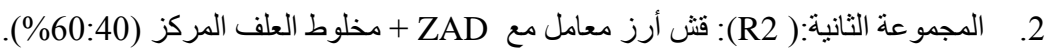

3. المجموعة الثالثة:( R3): قش الأرز المعامل مع EM + مخلوط العلف المركز (60:40\% ) .

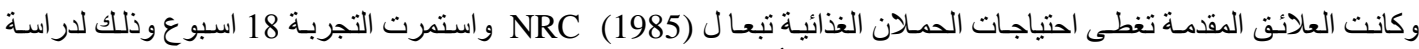

التركيب الكيماوي للقش المعامل, خصائص الدم المات , معدل النمو, المأكول من العليقة, كفاءة التحويل الغذائى و الكفاءة الاقتصادية.

$$
\text { وقد اوضحت التائج أن: }
$$

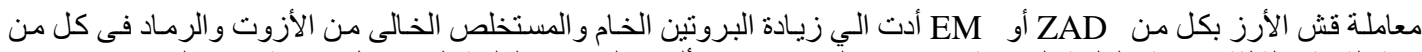

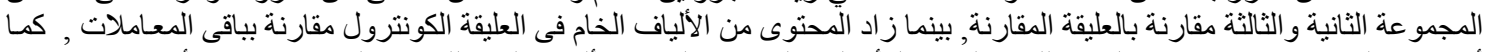

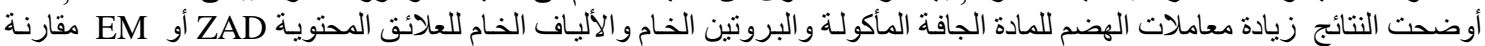

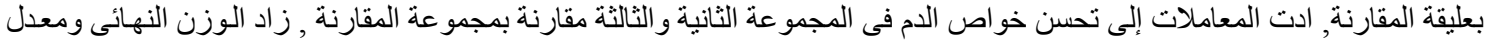

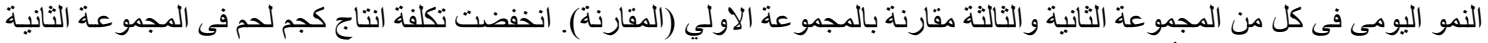
و الثالثة مقارنة بالمجمو عة الأولي (المقارنة).

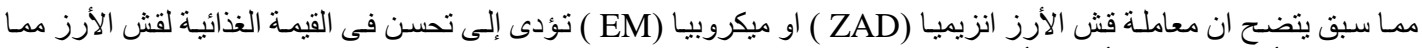

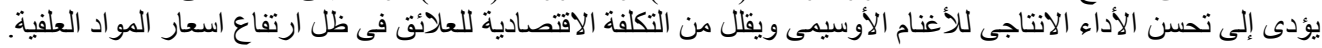

